\title{
Conditional okay for cannabis prescription drug
}

Health Canada has conditionally approved the first cannabisderived prescription pain killer. Cannabis sativa extract (Sativex), an under-the-tongue spray, was approved in April for use as an adjunctive treatment for the symptom relief of neuropathic pain in patients with multiple sclerosis (MS). The drug should be available by June 21 .

The approval is conditional on the manufacturer, UK-based GW Phamaceuticals, conducting more clinical trials to confirm efficacy. Health Canada gave conditional approval because the drug fills an "unmet need," said spokesperson Jirina Vlk.

About 160 patients with MS already obtain cannabis through the Marihuana Medical Access Program. The department won't know whether Sativex will reduce enrolment in that program for about a year, said Vlk. "People may try [Sativex], then switch back [to smoking marijuana]."

Underlying the approval is an unpublished, phase III randomized controlled trial involving 66 p patients with MS-related neuro- pathic pain; half took the drug and half placebo. The group receiving Sativex reported pain relief, less sleep disturbance and felt their condition had improved. Side effects included dizziness, nausea and fatigue.

"The data are okay, but not overwhelming," says Dr. Paul O'Connor, director of the St. Michael's Hospital MS Clinic Canada's largest, with 5000 patients. Results from previous trials, even one with 667 patients (Lancet 2003;362:1517-26), have not produced consistent results, adds O'Connor.

In December, the UK refused to approve Sativex for the control of spasticity in patients with MS. The UK Medicines and Healthcare Products Regulatory Agency raised concerns about whether the results of a recent trial are statistically relevant. GW, which is developing a "portfolio of cannabis medicines" to treat people with diabetes, spinal cord injury, cancer pain and more, is appealing the decision.

O'Connors says he is "pleased patients have another option"

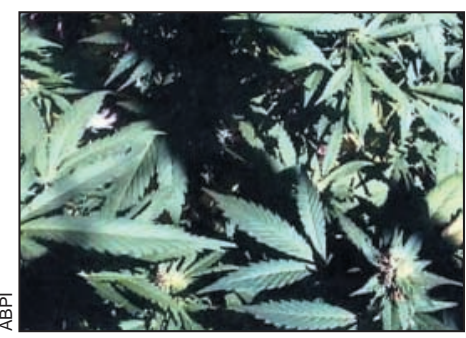

To meet demand for Sativex, GW Pharmaceuticals has increased production at its fortified greenhouses in the UK to 60 tonnes per year.

that offers a more controlled dose than smoked cannabis.

Many patients also want to control the "high" they get from smoking. Health Canada's statement of approval says that $70.5 \%$ of patients "experienced an adverse event classified as an 'intoxication type reaction,"' including "feeling drunk."

These adverse effects can be controlled by reducing the size or frequency of doses, says Dr. Tom Segerson of Bayer Canada, the division of GW in charge of distributing the drug here. Barbara Sibbald, CMAJ

\section{ReseARCH Ethics}

\section{New US guidelines for research on human embryos}

US embryonic stem cell researchers now have relief from the patchwork of regulations and funding restrictions they currently face.

In August 2001 the US president limited federally funded researchers to the use of tissue derived from several dozen human embryonic stem cell lines which were created before that time. This policy is still being debated, most recently in May, when the - US House of Representatives voted to extend federal funding for stem cell research, despite the threat of a presidential veto.

Meanwhile, state-level agencies, private industry and foundations are supporting research on stem cells derived from sources not approved by the National Institutes of Health. However, "Both the investigators and the institutions have been left with no guidance as to what's appropriate and what's not," says Richard Hynes, a cancer researcher at the Massachusetts Institute of Technology.

Hynes cochaired a US National Academy of Sciences (NAS) committee that issued guidelines in April on deriving, storing, distributing and using embryonic stem cell lines. Although the guidelines remain strictly voluntary, Hynes says institutions and state governments have responded positively. Harvard University and the State of California are adopting them.
The NAS guidelines call for Embryonic Stem Cell Research Oversight (ESRO) committees to ensure the guidelines are followed.

Among other things, the guidelines require donor consent before a blastocyst is used to generate stem cells. This mirrors the Canadian Institutes of Health Research stem cell guidelines.

The NAS guidelines also address the implications of introducing human cells into animals; the breeding of chimeras and the transfer of human attributes to animals is proscribed. The guidelines also disallow the transplantation of animal cells into human blastocysts. - Tim Lougheed, Ottawa 